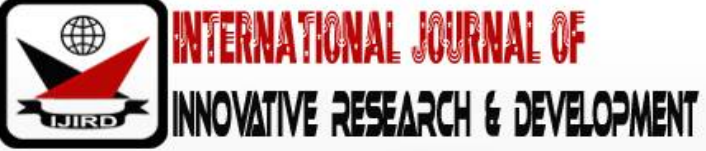

ISSN 2278 - 0211 (Online)

\section{Problems Causing in the Area of Health and Environment Due to Inappropriate Solid Waste Management in Jalingo Metropolis, Nigeria}

\author{
Saleem Isa Mohammed \\ Assistant Lecturer, Department of Geography, Taraba State University Jalingo, Nigeria \\ Abba Umar Jauro \\ Assistant Lecturer, Department of Geography, Taraba State University Jalingo, Nigeria \\ Dabo Mahmud Mohammed \\ Seismologist, Integrated Data Services Limited (Subsidiary of NNPC), Nigeria
}

\begin{abstract}
:
This study has highlighted the serious problem of Jalingo metropolis in terms of solid waste management and its affect on health of the residents and environment. It also highlighted many attempts which are taken to solve this dangerous increasing problem. Moreover it helps to identify places for dumping municipal wastes along with the health implication. The data for the study was sourced from a well-structured questionnaire and oral interview of the local residence in the area who are quite involve in generation and disposing of solid waste to the open dump site environment and the date obtained is presented in a simple statistics such as a simple percentage inform of tables and bar charts. The study shows that the majority of the inhabitants are really aware of the health implication of polluting environment with improper solid waste disposal and the major type of waste generated in the area are polythene bags, plastic materials, and food waste respectively. And most of these type of wastes are sourced and generated from the residential areas with their awareness of the health implications they might cause to the environment such as malaria caused by mosquitoes, cholera caused by houseflies, Lassa fever caused by infected Rats or mice and polluting the air with an unpleasant odor, all these above mentioned disease vectors require a dirty environments and as such they transmit disease to the inhabitant in the environment and these disease become most prevalent in the environment under study. It is finally recommended that proper waste collection cans be made available to the inhabitant, incinerators should be made available for burning wastes in a proper manner, good landfill be made available in a suitable locations and Governments should do more on treating waste properly and encourage recycling of waste capable of recycling such as plastics which will reduce the amount of wastes disposed in the environment.
\end{abstract}

Keywords: Solid waste management, health implication, environmental impact, Jalingo

\section{Introduction}

For government, society, environment, solid waste is an increased concern. This problem has become much more dangerous in Jalingo, where solid waste is increasing along with increment of population pressure. Nigeria is observing tremendous growth of town among other third world countries (Alakinde, 2013). This is created a pressure on waste management, electricity, roads. Educational institutions and housing are becoming less to handle this pressure. Generally solid wastes created from human and animal activities, are known as solid waste. (Okecha, 2000). Needles to say, these are unwanted and useless. These also consist of by-products of many product lines which need to be discarded. Based on many factors like basis of sources, environmental risks, utility and physical property, solid wastes can be categorized in many ways.

Municipal Solid Wastes, Industrial Solid Wastes and Agricultural Solid Wastes are some of the commonly classification of solid waste. A great effort has been noticed from urban centers of Nigeria for cleaning of solid wastes to keep environment clean. Heaps of solid wastes originated from household's kitchen, shopping mall, business centers. Without any doubt this solid waste are causing harmful effect on clean air, health. Officials are not able to show any effective step to clear it or to stop originating it. Moreover, sanitation laws, rules are getting effected by this waste. It has become a national issue for Nigeria. Health, environment, urban lifestyle dangerously affected by this. It has become a matter of realization for every stakeholder associated with the initiatives taken for safety and beautification purpose. According to Uwaegbelun (2004), residence of Nigeria is suffering a lot due to menacing side of solid wastes. As per a report by United Nations (2004) it had been highlighted that although many initiatives are taken by developing countries to improve drinking water but they are not able to successfully installed sanitation system. A study conducted by 
Uwaegbelun (2004) highlighted the joint report by World Health Organization and United Nations International Children Education Fund- "about 2.4 billion people will likely face the risk of needless disease and death by the target of 2016 because of bad sanitation". Moreover, leakage and bad sanitation system had been treated as main responsible factor behind diseases like cholera and diarrhea, which able to destroy a life of a child in every 21 seconds (WHO 2004; UNICEF 2004). It has become a very common problem that developing countries and their cities are suffering from poor water services, poor urban and industrial waste management, as well as air pollution. This problem has become a major burning problem for Nigeria. With origin of waste existence of human is interrelated. Many cities are not keeping pace with urbanization, pollution and ultimately ending up causing a heap of wastes. Cording to Uwaegbelun (2004), consumption patterns and lifestyle also influenced a lot for generating garbage. Publicizing of Decree58 had been taken place by the federal government of Nigeria under Environmental Protection Agency (FEPA) on 30 December1988 to take necessary actions. National policies also have been framed to take actions for environmental development, public awareness, health and welfare (FEPA 1989; FRN 1991). Proper collection and removal of waste are immediately required to keep environment safe. Proper enforcement of laws, penalties, environmental monitoring are very much important here.

Studies done by Agunwanba 1998; Adegoke 1989, and Singh1998, highlighted the negative side that these initiatives were not able to cause any serious improvement for waste management. The main interest lies in the beautification of environment which is most difficult to achieve. Failure occurs as collection of wastes are irregular, even not initiated at some places which recursively causing foul smell, diseases, water pollutions. The inappropriateness of bodies and rules are also seemed to be the reason behind this (Adegoke 1989, Singh1998). As an alternative initiative federal government had stared monthly environmental sanitation from early seventies which aimed to cure its own solid waste based on their nature. Wastes Management Boards (WMB) had been set up in almost every city to handle this. Problems also arise from blocked drains, traffic impedance and floods which are almost untouched yet. Another common problem is that this initiative consumes a lot of financial resources (Singh1998).

The primary objective of this study is to assess health hazards associated with solid wastes in Jalingo metropolis. It also looks into the problems which comes with this type of waste. It also discusses many attempts which have been taken for management of waste in Jalingo metropolis. Lastly it highlighted areas for dumping of wastes and its repercussion on human body.

\section{Materials and Method}

\subsection{Study Area}

For Jalingo LGA location is altitudes $8^{0} 47^{\prime}$ to $9^{0} 01^{\prime \prime} N$ and longitudes $11^{0} 09^{\prime}$ to $11^{0} 30^{\prime \prime} E$ approximately. North is surrounded by the Lau Local Government Area, Yorro Local Government Area is at the east, Ardo Kola Local Government Area situated at south and west respectively.

Approximately $195 \mathrm{~km}$ is the total local area ${ }^{2}$. According to Shawuluet al. (2008), 139,845 total population of this area (based on 2006 population census). It has a growth rate of 3\% per annum. As per Oruonye (2014), now it has 165,774 population.

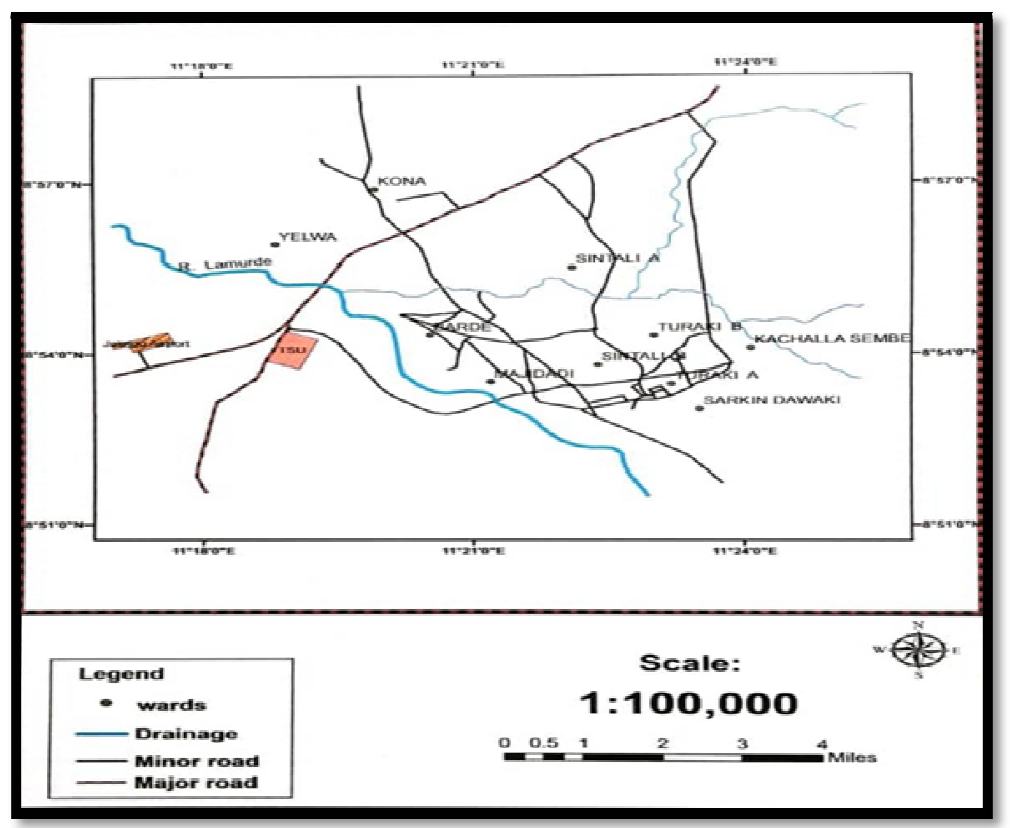

Figure 1: Map of Jalingo Showing Political Wards

Jalingo LGA has ripple plain along with some mountain ranges from Kona area to the border between Jalingo and Lau LGAs down to Yorroand Ardo Kola LGAs in a circular form to Gongon area. This semi-circle shape of mountain acts a protection barrier for Jalingo town. It has tropical continental type of weather. From April to October it has wet season and from November to March it has dry season. Mean of $1,200 \mathrm{~mm} 3$ is approximate rainfall annually occurs in the LGA. $29^{\circ}$ is 
the mean temperature of this area. For wet season the relative humidity is between $60-70$ per cent and for wet season it is between 35 - 45 per cent in the dry season. Jalingo has tall trees and shrubs, located within northern guinea savanna zone. Locust bean, shea butter, eucalyptus, baobab and silk cotton tree are some of the most commonly grown trees of this area. Fulani, Jibu Kona and Mumuye are the primary ethnic group of this area. Whereas, Hausa, Jenjo, Wurkum and Nyandang are some of the other groups found in this area. Hausa language is the main language spoken over here for communication purpose. Sangam has occurred between Lamurde and Mayo Gwoi rivers in Jalingo town around Magami ward.

A wide array of flood plain exists in the river Lamurde. Majority of residents live in the northern bank of river. This area has risk of flood. Southern bank is the suitable place for cultivation. According to Oruonye (2011), three times cultivation is the normal trend for this place. Along with the increment in population, new roads and bridges the use of land has changed. Musa (2002), mentioned that approximately 648,240m3 per year water can be extracted from Lamurde river. This river has stopped growing in southern part for long time.

The entire residents of the town are the population for this study. All male and female people having age 15 years and more are the population for this study.

\subsection{Method of Data Collection}

This is the process of handling mass data and summarizing it to interpretable values. In other words, data analysis involves treatment of data with statistical tools in order to simplify and make the data interpretable.

Data for this study will be collected from both primary and secondary sources. The primary source will be obtained via the use of structured questionnaire and oral interview as the case might be while secondary data will be obtained from journals, seminar papers, proceeding papers, newspapers etc.

\subsection{Method of Data Presentation}

Data analysis is a major step in any research work. It is the process of handling mass data and summarizing it to interpretable values. In other words, data analysis involves treatment of data with statistical tools in order to simplify and make the data interpretable. For this work, the gathered date will be presented in a simple statistics such as simple percentages in form of tables and pie chart will be used to present and analyze the data collected.

\section{Result and Discussion}

\subsection{Solid Waste Generation}

From the responses received through questionnaire and oral interview from the respondents, the precise amount of solid waste generated in the study are (Jalingo Metropolis) is determined so as to examine the nature of solid waste generated in Jalingo metropolis and the health implication the solid waste has on the local residents within the study area (Jalingo Metropolis). Similar studies by Yavivni (2013) indicated that the majority of the sources of solid waste in Jalingo metropolis are generated from local household, followed by commercial set up then solid waste generated from market places respectively. Table 1 shows that the respondents generate solid waste indicating 130 respondents representing $97.01 \%$ saying yes while 4 respondents representing $2.98 \%$ said no.

\begin{tabular}{|c|c|c|}
\hline Variables & Frequency & Percentage (\%) \\
\hline Yes & 130 & 97.01 \\
\hline No & 4 & 2.98 \\
\hline Total & 134 & 100 \\
\hline
\end{tabular}

Table 1: Do You Generate Solid Waste

Source: Field Survey, 2018

The type of solid waste generated and the influence on the health of individuals living around dump sites was also determined as in Table 2, and it was realized that 19 respondents representing 14.17\% opined food waste, 30 respondents representing $22.38 \%$ suggested leather, 17 other respondent $12.68 \%$ opined paper, 29 respondents representing $21.64 \%$ suggested plastic materials, 19 respondents representing $14.17 \%$ consider metals as the waste generated, while 20 respondents representing 14.9\% opined Unclassified Refuse. This implies that the major waste generated in the study area is Polythene.

\begin{tabular}{|c|c|c|}
\hline Variables & Frequency & Percentage (\%) \\
\hline Food waste & 19 & 14.17 \\
\hline Polythene & 30 & 22.38 \\
\hline Paper & 17 & 12.68 \\
\hline Plastic materials & 29 & 21.64 \\
\hline Metal & 19 & 14.17 \\
\hline Unclassified Refuse & 20 & 14.9 \\
\hline Total & 134 & 100 \\
\hline
\end{tabular}

Table 2: Types of Solid Waste the Respondents Generate at Home 
From the Table 3 given below, it indicated that the majority of the local resident within the study area are quite aware that there are health implications connected to an improper solid waste disposal managements. 85\% of the people in the area are quite aware of such implications as well as the diseases attached to such an improper solid waste managements in the study area.

\begin{tabular}{|c|c|c|}
\hline Variables & Frequency & Percentage (\%) \\
\hline Yes & 115 & 85.82 \\
\hline No & 19 & 14.17 \\
\hline Total & 134 & 100 \\
\hline
\end{tabular}

Table 3: Awareness of Health Implication of Improper Solid Waste Management

Source: Field Survey, 2018

On the health implications of improper waste management in the locality as shown in Table 4, 57 respondents which represents $42.53 \%$ opined malaria, 30 other respondents representing $22.38 \%$ indicated Cholera, 20 respondents representing $14.92 \%$ indicating unpleasant odor from decomposing substrate, 17 respondent's representing $12.68 \%$ are challenged with hepatitis, while 10 other respondents representing 7.46\% indicated Lassa fever as some of the improper solid waste disposal. This implies that improper solid waste management makes the respondents to be attacked by malaria as improper waste on an open dump site mixed with water attract mosquitos in an environments which the local residence within Jalingo metropolis become more prone to Malaria attack .This finding is in line with Uchegbu (1998), in his words said man unguided development and ineffective solid waste management in urban centers of Nigeria has resulted to urban degradation and outbreak of diseases like cholera, malaria, typhoid, bronchial disorders, etc.

\begin{tabular}{|c|c|c|}
\hline Variables & Frequency & Percentage (\%) \\
\hline Malaria & 57 & 42.53 \\
\hline Cholera & 30 & 22.38 \\
\hline Unpleasant odor & 20 & 14.92 \\
\hline Hepatitis & 17 & 12.68 \\
\hline Lassa fever & 10 & 7.46 \\
\hline Total & 134 & 100 \\
\hline
\end{tabular}

Table 4: Some Health Implication of Improper Waste Management in the Locality

The study from Table 5 also identified some vectors associated with improper solid waste management, this include mosquitoes with $58.20 \%$, housefly with $22.38 \%$, rats with $14.92 \%$ while those categorized as others had $8.97 \%$ representation. Waste is the most dangerous physical problem for people living in the earth (Edu, 2003). Whole lot of waste are being duped in everywhere like along streets, market, residential places. These wastes can create serious health hazards. It creates blockage for ground water supply as well as pollute it. It makes places ideal breeding ground for rats, cockroaches, flies, etc, which are the most responsible for spreading diseases. This study of Table 5 is correlated with table 4 which proof the relationship between the vectors and the subsequent diseases that these vectors cause within the community, example Mosquitos representing $58.20 \%$ as the highest vector in Table 5 is correlated with Malaria as the highest in Table 4 with $42.53 \%$ caused by Mosquitoes.

\begin{tabular}{|c|c|c|}
\hline Variables & Frequency & Percentage (\%) \\
\hline Mosquitoes & 78 & 58.20 \\
\hline Housefly & 30 & 22.38 \\
\hline Rats & 20 & 14.92 \\
\hline Others & 8 & 8.97 \\
\hline Total & 134 & 100 \\
\hline
\end{tabular}

Table 5: What Are Some Vectors in Your Community?

The study from Table 6 also found out that the respondents are aware that these vectors transmit diseases. This is represented with $83.58 \%$ agreement to this assertion and $16.41 \%$ with counter opinion.

\begin{tabular}{|c|c|c|}
\hline Variables & Frequency & Percentage (\%) \\
\hline Yes & 112 & 83.58 \\
\hline No & 22 & 16.41 \\
\hline Total & 134 & 100 \\
\hline
\end{tabular}

Table 6: Are You Aware That These Vectors Are Able to Transmit Disease

On the prevalence of diseases associated with improper solid waste management in Jalingo metropolis as in Table 7 and 8, the study shows 94 respondents representing 70.14\% indicated that diseases associated with improper waste disposal or management are prevalent, 23 respondents representing $17.13 \%$ indicated that it is highly prevalent while 17 respondents representing $12.68 \%$ opined not prevalent. The study also reveals that some of the health implications of 
improper solid waste management in the locality is malaria with 57 representing $42.53 \%, 30$ other respondents representing $22.38 \%$ indicated cholera, 20 respondents representing $14.92 \%$ indicating $12.68 \%$ opined unpleasant odour from decomposing substrate, 17 respondents $12.68 \%$ are challenged with hepatitis, while 10 other respondents representing 7.46\% indicated Lassa fever as some of the improper solid waste disposal. This finding agrees with the classification of Tchobanoglouset al (1993), solid waste is classified into types in terms of sources and generation facilities, activities or locations. It posited that wastes are generated, typical location and types of solid waste. Food waste was seen to be generated in all sources of waste.

\begin{tabular}{|c|c|c|}
\hline Variables & Frequency & Percentage (\%) \\
\hline Malaria & 83 & 61.94 \\
\hline Cholera & 30 & 22.38 \\
\hline Diarrhea & 19 & 14.17 \\
\hline Lassa fever & 2 & 1.49 \\
\hline Total & 134 & 100 \\
\hline
\end{tabular}

Table 7: The Prevalent Diseases Associated to Improper Solid Waste Management in Jalingo Metropolis

\begin{tabular}{|c|c|c|}
\hline Variables & Frequency & Percentage (\%) \\
\hline Prevalent & 94 & 70.14 \\
\hline Highly prevalent & 23 & 17.13 \\
\hline Not prevalent & 17 & 12.68 \\
\hline Total & 134 & 100 \\
\hline
\end{tabular}

Table 8: Prevalence of Diseases Associated Improper Solid Waste Disposal Source: Field Survey, 2018

Table 9. reveals the sources of solid waste in the community, 85 respondents representing $63.43 \%$ opined residential wastes, 26 respondents representing 19.40\% suggested Market places, 14 respondents representing $10.44 \%$ indicated special waste from hospitals and related health institutions while 9 respondents representing $6.71 \%$ indicated ewaste i.e. electronic waste disposed from sources like damaged mobile phones, Laptops, televisions etc.

\begin{tabular}{|c|c|c|}
\hline Variables & Frequency & Percentage (\%) \\
\hline Residential & 85 & 63.43 \\
\hline Market Places & 26 & 19.40 \\
\hline Special waste from hospitals & 14 & 10.44 \\
\hline E-waste & 9 & 6.71 \\
\hline Total & 134 & 100 \\
\hline
\end{tabular}

Table 9: Sources of Solid Waste in Jalingo Metropolis and Their Effects on the Environment

Table 4.2.14: Sources of Solid Waste in the Community

Source: Field Survey, 2018

Table 10 shows the problems of public health and environment in Jalingo as 56 respondents representing 41.79\% opine Disease Infection, 36 respondents representing 26.86\% indicate Pollution, while 42 respondents representing $31.34 \%$ opined that it gives the environment a nasty outlook.

\begin{tabular}{|c|c|c|}
\hline Variables & Frequency & Percentage (\%) \\
\hline Disease Infection & 56 & 41.79 \\
\hline Pollution & 36 & 26.86 \\
\hline $\begin{array}{c}\text { Nasty sight on the } \\
\text { environment }\end{array}$ & 42 & 31.34 \\
\hline Total & 134 & 100 \\
\hline
\end{tabular}

Table 10: Problems of Public Health and Environment in Jalingo

Source: Field Survey, 2018

\section{Conclusion}

From the study conducted on the health and environmental impact of improper solid waste management in Jalingo Metropolis, it has been concluded that indeed the dwellers in the study area do generate solid waste that may in the other way become more harmful on the health of the people within the community, and most of the wastes generated by the individuals within Jalingo metropolis are polythene bags which the researcher believes that it doesn't have a direct health impact on Human in terms of the waste disposal, but when disposed on a drainage channels, it create blockage on the drainages mixed up with water and garbage, Hence creating a conducive environment for breeding disease vectors such as mosquitoes, Houseflies, Rats, cockroaches as listed in Table 5 which are then capable of generating and spreading 
of diseases to the inhabitant in the Jalingo metropolis. And that the majority of the citizens are quite aware of the health implications associated to such vectors hence practicing an improper solid waste management. The major disease caused by this vector is malaria parasite which the residence suffers the most with mosquitoes being the vector of such disease. It has been concluded further that malaria parasite is more dominant caused by mosquitos raised at the open dump site within the metropolis. As mentioned above, that the major types of solid waste in Jalingo are polythene bags, plastic materials, and food wastes respectively, and all of these are believed to have been sourced from domestic environment or a residential buildings.

\section{Recommendation}

The following recommendations were made based on the research that was conducted;

- Waste collection cans should be made available to collect waste properly before they taken for proper disposal,

- Incinerators should be made available to burn those waste that are most appropriate for burning,

- Good landfills should be made available in suitable locations,

- Government should ensure wastes are properly treated before they are disposed,

- Monthly sanitation should enforce on every resident to ensure cleaning of the environment.

\section{Reference}

i. Adegoke, O.S., (1989) Waste management within the context of sustainable development. Proceedings of the Environment and sustainable Development in Nigeria workshop, 25- 26 April, Abuja Nigeria. [[ 103-110

ii. Agunwamba, J.C., Ukpai, O.K. and Onyebueyi, I.C (1998): Solid Waste Management in Onitsha, Nigeria. Journal of Waste Management Research.16(1).23-31.

iii. FEPA 1998 (Federal Environmental Protection Agency). 1989. National Policy on the Environment. Nigeria: FEPA, P. 22.

iv. FRN (Federal Republic of Nigeria) 1991. Official Gazette 78 (42): B15 - B37. Federal Military Government 1988. Federal Environmental Protection Agency Decree No. 58: A 911 - A 932.

v. Okecha S.A (2000). Pollution and conservation of Nigeria n Environment. Afrique International Associates Owerri, Nigeria.

vi. Omole, F.K, and M.K. Alakinde., (2013). Managing the unwanted materials: The agony of solid waste management in Ibadan metropolis, Nigeria. International journal of Education and research 1 (4) pp 1-12

vii. Oruonye, E. D. (2011). An Assessment of Fadamadry Season Farming Through Small Scale Irrigation System in Jalingo LGA, Taraba State. International Research Journal of Agricultural Science.Vol.1 (1). Pp. 014 - 019.

viii. Oruonye, E. D. (2014). "An assessment of the impact of road construction on land use pattern in urban centres in Nigeria: A case study of Jalingo LGA, Taraba State Nigeria," Mediterranean Journal of Social Sciences, vol. 5, pp. 8288, 2014.

ix. Singh, S.K., (1998). Solid waste management: an overview of environmental pollution, Environmental control Journal, 1 (3): pp 50-56.

x. Tchobanoglous, G. et al.: Integrated solid waste management - engineering principles and management issues, MCGraw-Hill, New York et al. 1993

xi. United Nation Development Programme, (2004). Municipal Solid Waste Management in Developing Countries; A Policy Framework. Geneva. Technical Paper, 12 Geneva UNDP.

xii. Yavini, T.D., Musa, A.A (2013). Municipal solid waste and pollution management in Jalingo metropolis. Problems, challenges and strategies. Journal of environment, Vol. 2 issue 05 pp 125-133 


\section{Appendix}

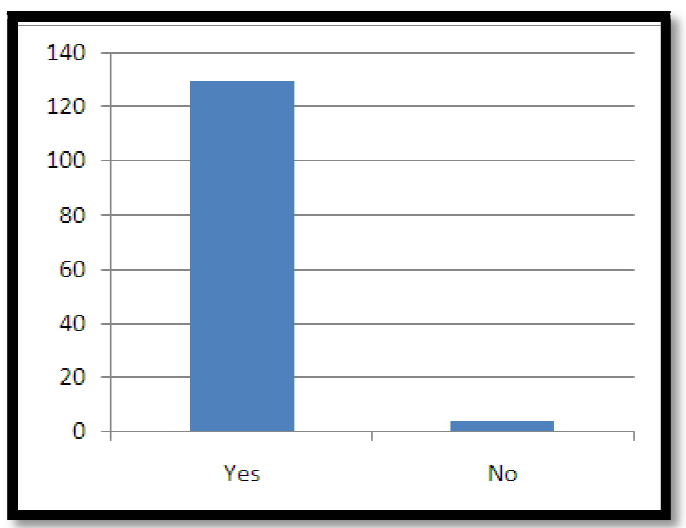

Figure 2: Do You Generate Wastes from Your Home?

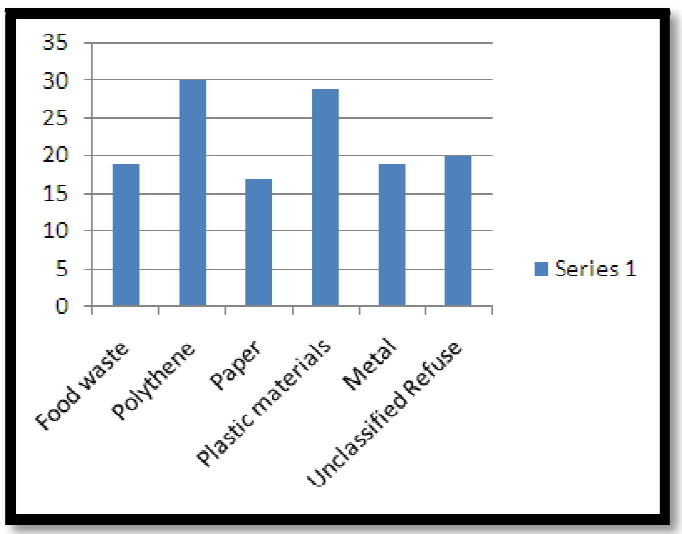

Figure 3: Types of Waste the Respondents Generates

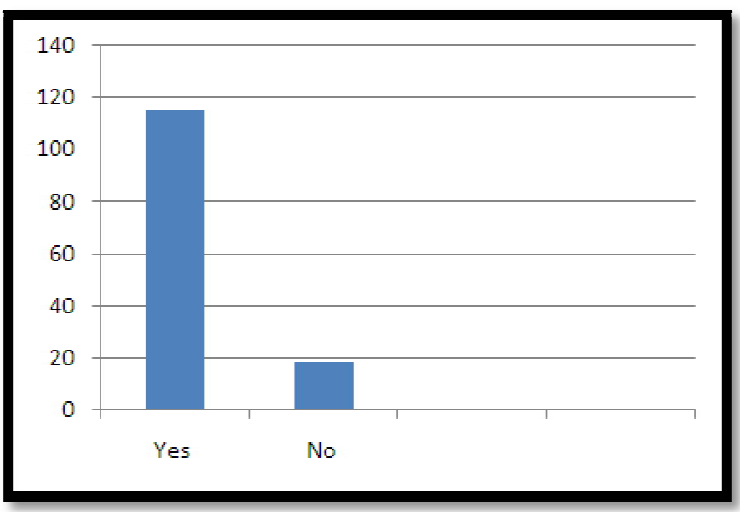

Figure 4: Are You Aware of Health Implication of Improper Solid Waste

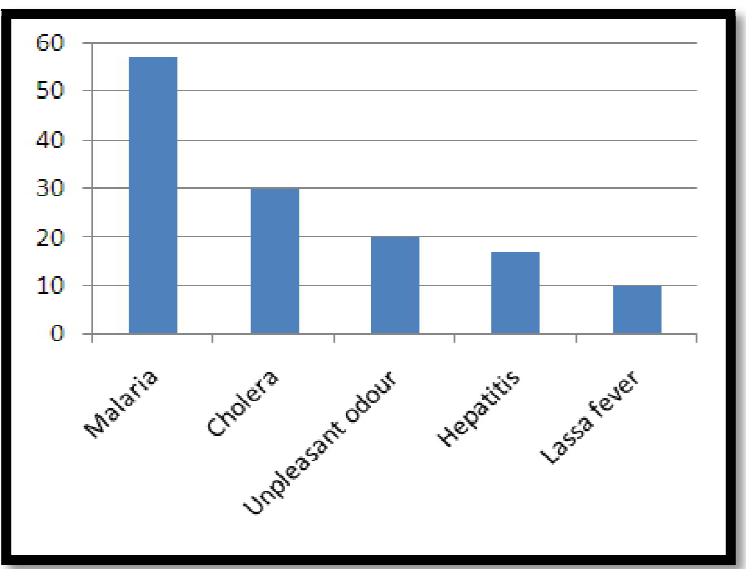

Figure 5: Health Implication of Improper Waste Management 


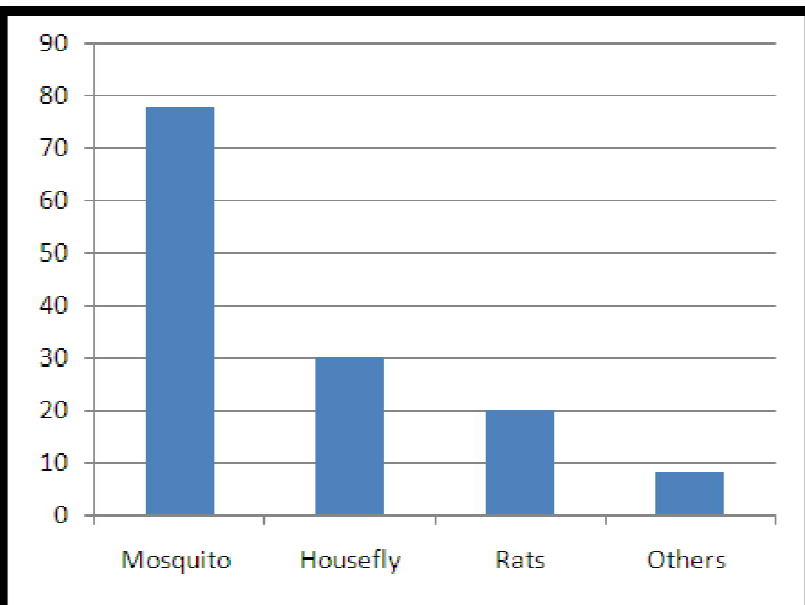

Figure 6: What Are Some Vectors in Your Community?

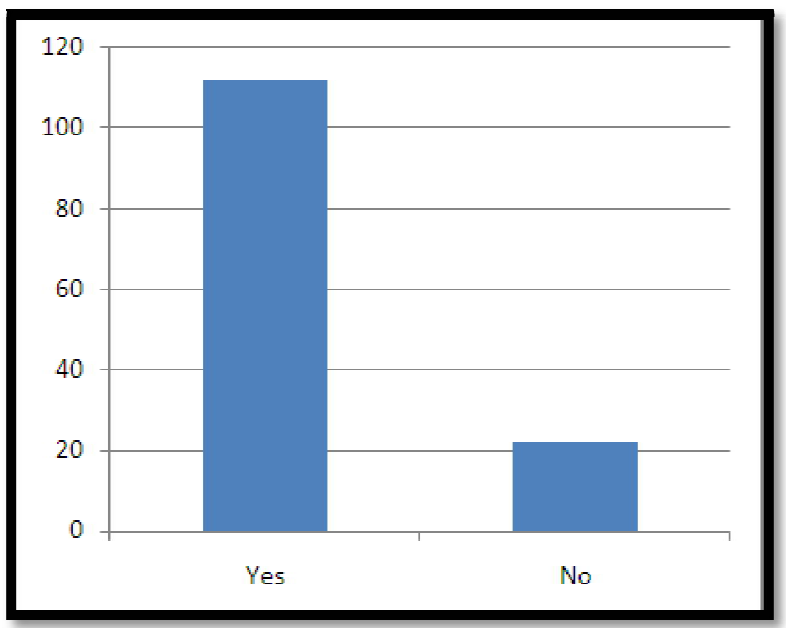

Figure 7: Are You Aware That the Vectors Are Able to Transmit Disease?

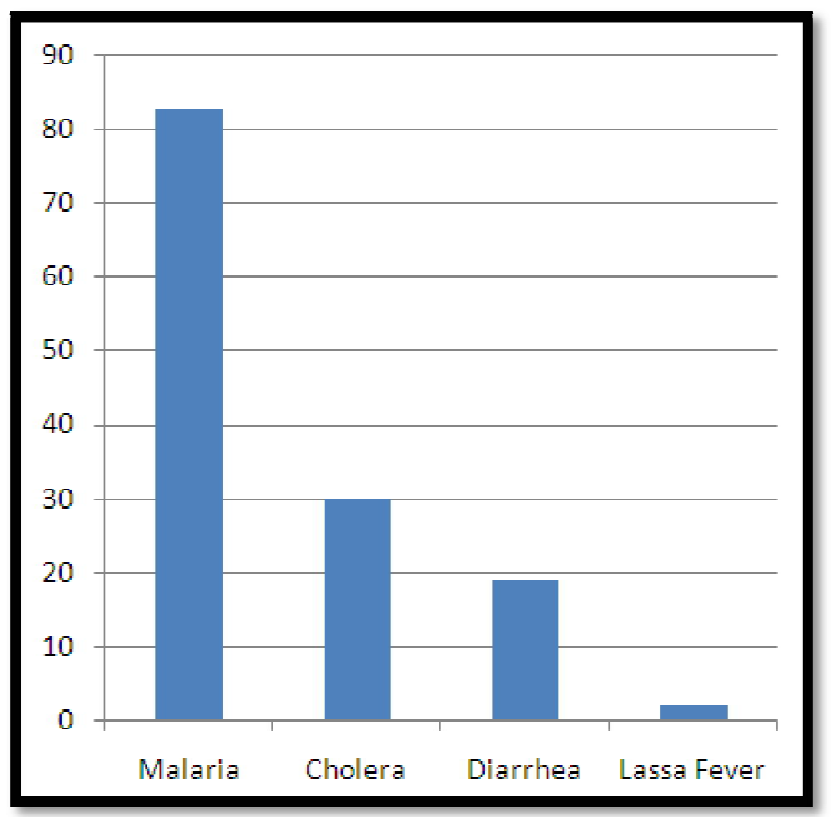

Figure 8: The Prevalence of Diseases Associated to Improper Solid Waste in Jalingo Metropolis 


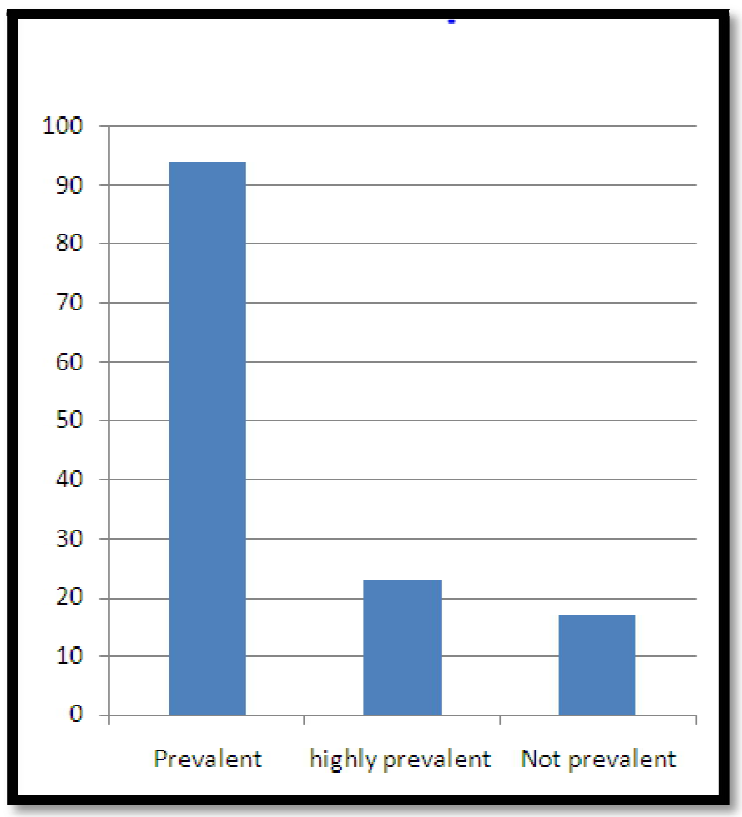

Figure 9: Prevalence of Diseases Associated Improper Solid Waste Disposal

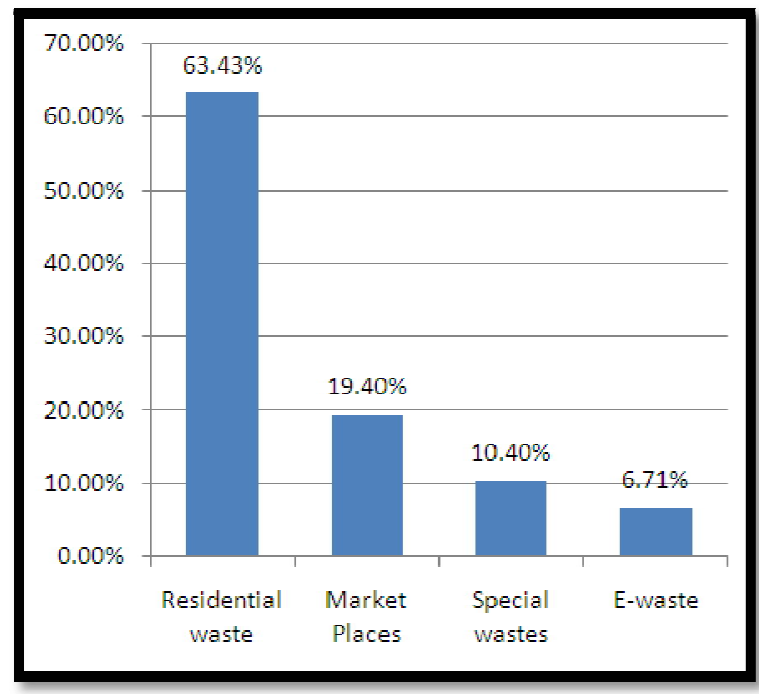

Figure 10: Sources of Solid Wastes in the Community

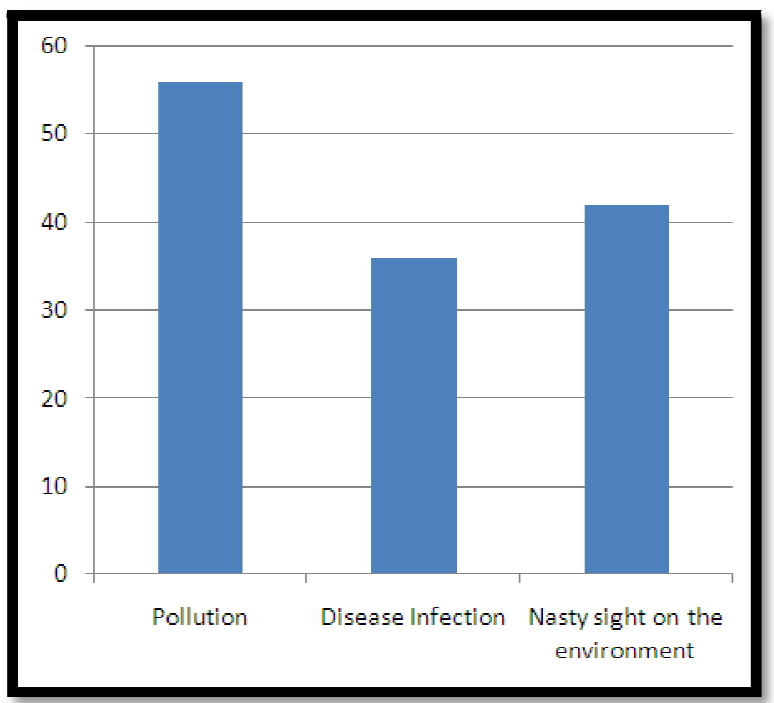

Figure 11: Problems of Public Health and Environment in Jalingo 


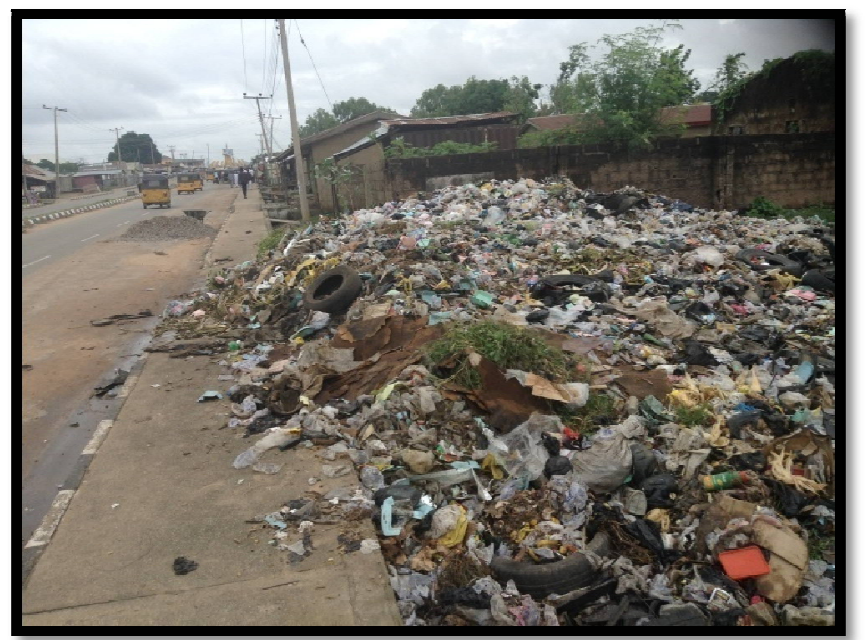

Figure 12: Solid Waste along Mayo Dasa in Kona Ward

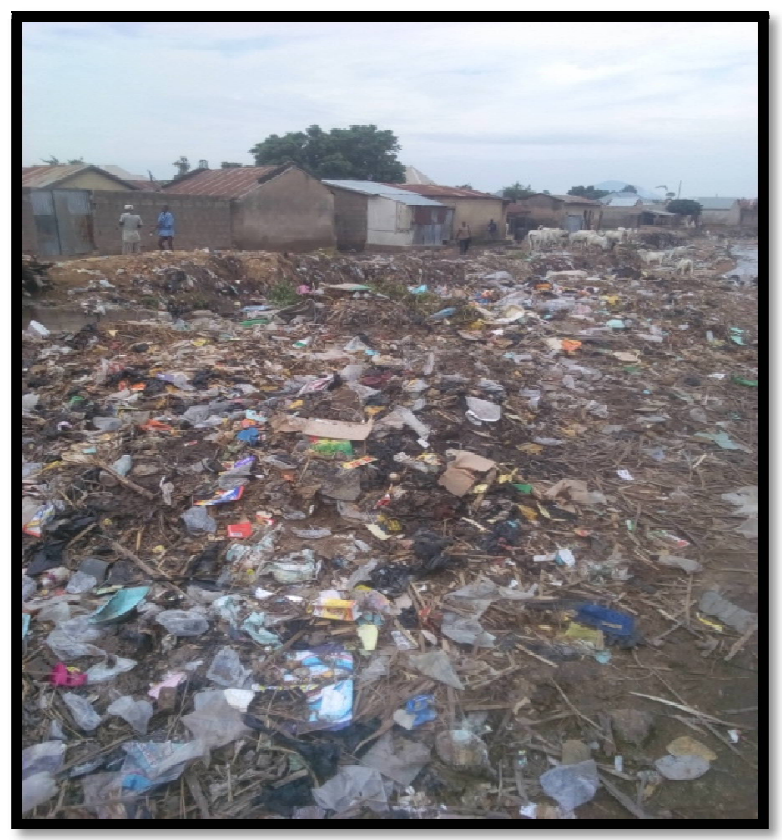

Figure13: Solid Waste at GadanBoboji (Majidadi Ward)

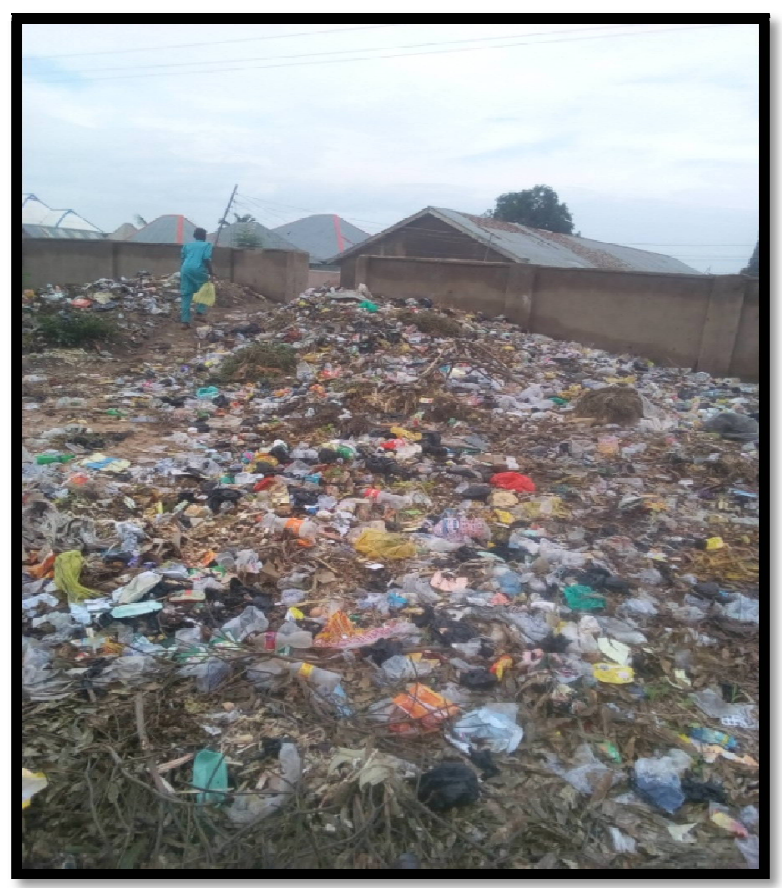

Figure 14: Solid Wastes at Magami 